\title{
Innovative milestones in Ophthalmology
}

\section{Hitos innovadores en la oftalmología}

Jaime Lozano-Alcázar*

Medical Direction department, Fundación Hospital Nuestra Señora de la Luz, Mexico City, Mexico

\begin{abstract}
Every physician is potentially a researcher. Important contributions to medicine development have been due to fortuitous observations. In Ophthalmology, for example, the initial idea of endophotocoagulation was the effect of a solar eclipse; a dental device resulted in phacoemulsification; the comment of a medical student led to intraocular lenses. But, as Pasteur said: "Dans les champs de l'observation, le hasard ne favorise that esprits préparés" (in the fields of observation, chance favors only the prepared mind). Some authors and their contributions to the development of Ophthalmology are presented here, hoping that their example will serve to arouse or increase interest in research.
\end{abstract}

Key words: History of Ophthalmology. Innovative ophthalmologists. Advances in Ophthalmology.

\section{Resumen}

Todo médico es potencialmente un investigador. Grandes aportaciones al desarrollo de la medicina se han debido a hechos fortuitos. En la oftalmología, por ejemplo, el efecto de un eclipse de sol fue la idea inicial de la endofotocoagulación; un aparato dental dio lugar a la facoemulsificación; el comentario de un estudiante de medicina despertó la idea de los lentes intraoculares. Pero, como dijo Pasteur: "Dans les champs de l'observation, le hasard ne favorise que les esprits préparés» (en el campo de la observación, la fortuna solo favorece a los espiritus preparados). Se presentan aquí algunos personajes y sus principales aportaciones al desarrollo de la oftalmología, esperando que su ejemplo sirva para despertar o avivar el interés por la investigación.

Palabras clave: Historia de la oftalmología. Oftalmólogos innovadores. Avances en oftalmología.

The formidable advances that medical and surgical diagnosis and therapeutics have had in recent decades in our specialty could not have been carried out without the foundations that were forged from the earliest antiquity, often due to empirical knowledge, which today is usually underrated.

Research in a more formal way began in the second half of the 19th century. We will now look at some of the most outstanding contributions, with the intention of not only remembering the researchers and their contributions as a historical anecdote, but rather so that in some way they serve as a stimulus to current researchers. Every doctor, at least potentially, is an investigator.

Of course, the great trigger for the consolidation of ophthalmology as a specialty was the invention of the ophthalmoscope, and for both specialty surgery and surgery in general, the application of anesthesia and antisepsis.

Correspondence:

*Jaime Lozano-Alcázar Ezequiel Montes,

135 Col. Tabacalera

Date of reception: 06-01-2020

Date of acceptance: 11-02-2020

E-mail: Drjaimelozano@gmail.com 2604-1731/@ 2020 Sociedad Mexicana de Oftalmología. Published by Permanyer. This is an open access article under the CC BY-NC-ND license (http://creativecommons.org/licenses/by-nc-nd/4.0/). 
On this topic, the mention of the two greatest figures of the $18^{\text {th }}$ century for the development of medicine cannot be ignored. One, the great Louis Pasteur (1822-1895), French biologist, microbiologist, and chemist, recognized for vaccination, especially for rabies and anthrax, for the sterilization of milk and beer through pasteurization, and for multiple investigations on microbiology: its relationship with diseases and its application in clinical medicine. It is known that he put an end to the theory of spontaneous generation, until then so accepted. In direct relation to our specialty, he discovered Pasteurella septica, which causes hemorrhagic septicemia in birds and that may cause conjunctivitis in farmers ${ }^{1}$. The other great figure is Joseph Lister (1827-1912), the English surgeon who applied Pasteur's discoveries to surgery. He insisted on sterile surgery using asepsis and antisepsis, and introduced sterilization of the instruments and of the surgical wound using carbolic acid (phenol). He proposed that the handles of surgical instruments should not be made of porous materials. He also advocated for surgeons handwashing before and after surgery, as Ignaz Semmelweis (1818-1865) in Switzerland and Oliver Wendell Holmes (1809-1894) in the USA had previously postulated. Regarding ophthalmology, Lister investigated the iris musculature. His main research assistant was his wife Agnes ${ }^{2}$.

Friedrich Wilhelm Ernst Albrecht von Gräfe (18281870), as it can be seen, died very young, at just 42 years old, of pulmonary tuberculosis, but left a memorable mark. He is considered the most important ophthalmologist of the $19^{\text {th }}$ century. He introduced iridectomy for glaucoma management; identified lagging of the upper eyelid on downward rotation of the eye in patients with thyroid orbitopathy (von Gräfe's sign), and described progressive external ophthalmoplegia. In 1855 he founded the Archiv für Ophthalmologie journal, which still exists, and in 1863, the Deutsche Ophthalmologische Gesellschaft . He designed the famous blade named after him, which was still used in cataract surgery in the middle of the last century. His main skill was to assertively apply the contributions of others, in particular the Helmholtz ophthalmoscope. Thus, he was the pioneer in describing, interpreting and drawing the fundus and its alterations; described the correlation between retinitis pigmentosa and deafness in Usher syndrome and papilledema in four patients with brain tumor; he was the first to keep a graphical record of altered campimetries; began the examination of ocular tumors by transillumination, and also promoted the use of the tonometer ${ }^{3}$.
Louis de Wecker (1832-1906), of French origin but born in Germany, had a successful clinic for eye diseases in Paris. He was the inventor of filtering surgery for chronic glaucoma (anterior sclerotomy) ${ }^{4}$, which he presented in 1856, 2 years after von Gräfe unveiled his iridectomy. Later, in 1900, it was published internal filtering surgery, called cyclodialysis, and in 1932, cyclodestruction. More than 150 years after the contributions of von Gräfe, Wecker and others, the four methods consisting on solution of pupillary block, external filtration, internal filtration and decreased production of aqueous humour are still the basic techniques in the surgical management of glaucoma. Trabeculectomy, published by Cairns in 1968, soon became the reference technique for filtering surgeries, although non-penetrating filtering surgeries emerged at the same time, but were not widely accepted. Soon after, in 1969, Molteno introduced the first effective filtering device. Since 1995, most new glaucoma surgical techniques have advocated the use of implantable external or internal filtration devices such as iStent, ExPRESS, SOLX ${ }^{5-7}$, and others, grouped under the term MIGS.

Manuel Uribe y Troncoso (1867-1959) was born in Toluca, Estado de Mexico. He attended patients at the Hospital de la Luz. In 1893 he was a signatory of the constitutive act of the Ophthalmological Society, today the Sociedad Mexicana de Oftalmología, the first society of medical specialists created in Latin America. He founded, in 1898, Anales de Oftalmología, currently named Revista Mexicana de Oftalmología, the oldest journal of the specialty in Spanish. In 1900 he was the guest of honor of the American Medical Association at the congress held in Atlantic City; in 1910 he was delegate of Mexico to the International Congress of Hygiene in Berlin, and in 1921, to the International Congress of School Hygiene in Paris, as he was Head of the School Hygiene Service and Medical Inspector General of the Schools of the Federal District and founder of the Annals of School Hygiene, founder of the Department of Educational Psychology and School Physician, dependency of the Secretary of Public Education since 1908. He was a professor at the Faculty of Medicine of the Universidad Nacional de México until 1916, when for political reasons he went to live in exile in New York. That same year he was appointed Professor of Ophthalmology at the New York Graduate Medical School and Hospital (in 1926 he became full professor) and was the founder of the Hispanic American Medical Society. In 1932 he entered the College of Physicians and Surgeons at Columbia University and Presbyterian Hospital. Later, the University of New York 
gave him the appointment of Extraordinary Professor of Ophthalmology. In 1933 he attended the XIX International Congress of Ophthalmology in Madrid as Delegate of Columbia University, and was later invited to give lectures in Valencia, Barcelona, Paris, Oxford, the Moorfields Eye Hospital in London, among others. He was a member of the New York Academy of Medicine, the French Ophthalmological Society, the Laboratory of the Columbia University Ophthalmological Institute, the Belgian Ophthalmological Society, an honorary member of the Hispano-American Ophthalmological Society of Madrid and editor for the American Journal of Ophthalmology. In 1942 he received the Annual Research Award from the American Medical Association. The following year, the Ministry of Public Assistance of Mexico awarded him a decoration, and on May 15, 1943, by presidential decree of Don Manuel Ávila Camacho, he was appointed Founding Member of the National College. Obviously, all these distinctions were due to his effective investigations in the field of Ophthalmology. $\mathrm{He}$ is considered the father of clinical gonioscopy; he created, among others, a self-illuminated monocular gonioscope, a binocular corneal microscope and an eye model for demonstration of ametropias. He published over 170 scientific articles and the books Internal Diseases of the Eye and Atlas of Gonioscopy ${ }^{8}$. Internationally, he is the most recognized Mexican ophthalmologist.

Jules Gonin (1870-1935), Swiss ophthalmologist. In the early $20^{\text {th }}$ century, after intensive and productive research into the pathophysiology of retinal detachment and the significance of retinal tears, he devised ignipuncture, the first effective method to treat retinal detachment by cauterizing tissue to create an inflammatory focus that induces scarring and thus, adhesion. He presented his method in 1919 to the Swiss Ophthalmological Society, but it took several years for him to receive credit (with the contribution of testimonies from Arruga, Amsler and Veil) ${ }^{9,10}$. Given the high risk of complications, the technique was replaced, years later, by photocoagulation.

Sir William Stewart Duke-Elder (1898-1978), English ophthalmologist, tireless bibliographic researcher. Among many others, he published two monumental works: the 7-volume Text Book of Ophthalmology and the 15-volume System of Ophthalmology. He stood out as director of research at the London Institute of Ophthalmology ${ }^{11}$.

Hans Goldmann (1899-1991), was born in Austria-Hungary and studied medicine in Prague. After being an assistant to Anton Elschnig, he made notable contributions that are still valid. Thanks to him, we have the slit lamp as we now know it, the perimeter, the three-mirror lens, the applanation tonometer, the adaptometer, the fluorophotometer and the colorimeter, of course, all named after Goldmann. He received the Gonin Medal and honorary doctorates from the universities of Uppsala, Strasbourg and Geneva ${ }^{12}$.

Sir Nicholas Harold Lloyd Ridley (1906-2001). This English surgeon was the inventor of the intraocular lens for the rehabilitation of aphakia. The comment of a medical student who saw him extract a cataract and asked why he did not replace the lens, inspired him to create the intraocular lens, selecting polymerized methyl methacrylate as a material, since he had observed that intraocular foreign bodies of that material remained inert in pilots of the Royal Air Force; the Spitfire cabins were made of that material. At St. Thomas Hospital, London, on November 29, 1949, he made the first implant. The eye was left with a 14-diopter myopia, but he improved calculations in such a way that the second eye was only left with 1 negative diopter ${ }^{13}$. During World War II, while serving in the English Army in the East, he studied onchocerciasis, the action of cobra venom in the eye, and nutritional amblyopia ${ }^{14}$.

Gerhard Rudolph Edmund Meyer-Schwickerath (1920-1992) was a German ophthalmologist. He is considered the father of retinal endophotocoagulation and of the eye surgeries that derived from it. He had the opportunity to examine several patients with retinal burns after observing the solar eclipse of July 9, 1945, and in 1946-1947 he concluded that the resulting scars were from an effect similar to that of surface diathermy that was already used for retinal detachment surgery. Applying Gonin's postulates, he deduced that with scars caused by sunlight at precise sites, he could stop the progress of retinal detachments and began the first experiments with photocoagulation. In 1949, he obtained the first successful treatment on the roof of the University of Hamburg Ophthalmology Clinic, Eppendorf, with an apparatus designed by him that through a system of magnifying glasses and mirrors allowed to focus sunlight into the eye. Unfortunately, cloudy days prevented treatment, so around 1950 he developed, with the Zeiss company, the "high-pressure xenon gas discharge-lamp" which, obviously, was no longer dependent on the sun. Later, xenon photocoagulators were replaced by those that use laser energy, as we all know ${ }^{15,16}$.

Charles D. Kelman (1930-2004). He did his residency at the Wills Eye Hospital in Philadelphia, and worked at the Manhattan Eye, Ear and Throat Hospital in New 
York. In 1992, he received the National Medal of Technology from President George H. W. Bush, and was included in the National Inventors Hall of Fame in Akron, Ohio, for his invention of the phacoemulsifier and the description of the surgical technique. According to him, phacoemulsification was inspired by the ultrasound instrument that his dentist used ${ }^{17}$.

I do not want to end without mentioning that in addition to Dr. Uribe and Troncoso, other Mexican ophthalmologists have made important contributions that have been documented; unfortunately, it is not easy to find bibliographic citations, but doing a brief recall I remember some examples in the surgical field.

Dr. Arcadio Chacón Mendoza, in the Bulletin of the Hospital Oftalmológico de Nuestra Señora de la Luz, volume XV, year XXIII, No. 46, second period, July to September 1962, pages 125 to 129, describes for the first time, according to the writing itself, the maneuver that bears his name for the management of congenital dacryostenosis and that earned him wide international recognition. On the walls of his office in Mexicali, BC, there were diplomas from European and American ophthalmology societies where he was appointed corresponding member.

Dr. Antonio Torres Estrada, described a technique, among others, for managing the ectropion of the lacrimal punctum, which was called "Torres Estrada stitch", which is still fully in force.

Dr. Luis Sánchez Bulnes, among other notable achievements, devised the technique of "radiated incisions" to make a natural "strap" to the eyeball to manage retinal detachment.

\section{Conclusion}

To conclude, I would like to instill the idea that potentially every ophthalmologist can do research that leads to valuable insight. As we have seen, the initial idea of endophotocoagulation was the effect of an eclipse of the sun, a dental appliance led to phacoemulsification, the observation of a medical student helped devise intraocular lenses, and we can just wonder how many other fortuitous causes there may be in history. The important thing is to know how to take advantage of an initial idea, for that what Pasteur says is necessary: «Dans les champs de l'observation, le hasard ne favorise que les esprits préparés» (in the fields of observation, chance favors only the prepared mind).

\section{References}

1. Duke-Elder S. Diseases of the Outer Eye. Vol. VIII, part 1. En: Duke-Elder S, editor. System of Ophthalmology. London: H. Kimpton; 1965. p. 210.

2. Duke-Elder S, Wylar KC. The Anatomy of the Visual System. Vol. II. En: Duke-Elder S, editor: System of Ophthalmology. London: H. Kimpton; 1961. p. 178-9.

3. Duke-Elder S. The Foundations of Ophthalmology. Vol. VII. En: Duke-Elder S, editor: System of Ophthalmology. London: H. Kimpton; 1962. p. 232-3.

4. Duke-Elder S. Diseases of the Lens and Vitreous; Glaucoma and Hypotony. Vol. XI. En: Duke-Elder S, editor. System of Ophthalmology. London: H. Kimpton; 1969. p. 228.

5. Razeghinejad MR, Spaeth GL. A History of the Surgical Management of Glaucoma. Optom Vis Sci. 2011;88(1):E39-47.

6. Molteno AC. New Implant for Drainage in Glaucoma. Br J Ophthalmol. 1969;53:606-15.

7. Cairns JE. Trabeculectomy. Premilinary Report of a New Method. Am J Ophthalmol. 1968;66(4):673-9.

8. http://colnal.mx/members/manuel-uribe-troncoso. Último acceso: 20 de febrero de 2018

9. Duke-Elder S, Dobree JH. The Retina. Vol. X. En: Duke-Elder S, editor. System of Ophthalmology. London: H. Kimpton; 1967. p. 771-3.

10. Hernández-DaMota SE. Historia de la cirugía del desprendimiento de retina hasta Gonin. Rev Mex Oftalmol. 2008;82(5):331-4.

11. https://en.wikipedia.org/wiki/Stewart_Duke-Elder. Último acceso: 20 de marzo de 2018.

12. https://en.wikipedia.org/wiki/Hans_Goldmann. Último acceso: 20 de marzo de 2018.

13. Ridley $\mathrm{H}$. The Cure of Aphakia. The History of Lens Implantation. Section 3. En: Rosen ES, Hainning WM, Arnott FJ, editors. Intraocular Lens Implantation. St Louis: The C. V. Mosby Co. 1984. p. 37-42.

14. https://en.wikipedia.org/wiki/Harold_Ridley_(ophthalmologist. Último acceso: 21 de febrero de 2018.

15. https://en.wikipedia.org/wiki/Gerhard_Meyer-Schwickerath. Último acceso: 21 de febrero de 2018.

16. Duke-Elder S, Mac Fane A, Injuries. Vol, XIV, n.ํㅡㄹ 2. En: Duke-Elder S, editor. System of Ophthalmology. London: H. Kimpton; 1972. p. 897.

17. https://en.wikipedia.org/wiki/Charles_Kelman. Último acceso: 21 de febrero de 2018. 